\title{
Archaeological Investigations at the Marshall Powdermill and Arsenal (41HS17), Confederate States of America 1864-1865, Harrison County, Texas
}

Thomas E. Speir

Unknown

David H. Jurney

Follow this and additional works at: https://scholarworks.sfasu.edu/ita

Part of the American Material Culture Commons, Archaeological Anthropology Commons, Environmental Studies Commons, Other American Studies Commons, Other Arts and Humanities Commons, Other History of Art, Architecture, and Archaeology Commons, and the United States History Commons

Tell us how this article helped you.

This Article is brought to you for free and open access by the Center for Regional Heritage Research at SFA ScholarWorks. It has been accepted for inclusion in Index of Texas Archaeology: Open Access Gray Literature from the Lone Star State by an authorized editor of SFA ScholarWorks. For more information, please contact cdsscholarworks@sfasu.edu. 
Archaeological Investigations at the Marshall Powdermill and Arsenal (41HS17), Confederate States of America 1864-1865, Harrison County, Texas

\section{Creative Commons License}

\section{(c) (1) (8)}

This work is licensed under a Creative Commons Attribution-NonCommercial 4.0 International License 


\title{
ARCHAEOLOGICAL INVESTIGATIONS AT THE MARSHALL POWDERMILL AND ARSENAL (41HS17), CONFEDERATE STATES OF AMERICA 1864-1865, HARRISON COUNTY, TEXAS
}

\author{
Thomas E. Speir and David H. Jurney
}

The Northeast Texas Archeological Society (NETAS), in conjunction with the East Texas, Dallas, and Tarrant County Archeological Societies has completed a year-long project at the Marshall Powder Mill, 41HS17, Harrison County, Texas. The Marshall Powder Mill manufactured gunpowder, small arms and cannon, and refurbished weaponry. It is one of several arsenals that served the Trans-Mississippi Department of the Confederate States of America, and was among the last in operation from 1864 to 1865 . None have been thoroughly investigated archaeologically, thereby ignoring a major aspect of the Confederacy's war effort and an important industrial enterprise.

The last professional archaeological investigations of the Marshall Powder Mill were conducted in the southern third of the site by the Texas Highway Department in the 1970s, when the Loop 390 bypass was constructed on the northern outskirts of Marshall (Weir 1973: Luke 1978:137). Three building foundations and an artifical pond were investigated, none of which were actually the mill it- self. Since then, the site has suffered extensive relic collecting, which increased significantly with the use of metal detectors.

Members of the Northeast Texas Archeological Society persuaded some of the landowners to restrict such looting and to allow a detailed reevaluation of the site. Building foundations, earthworks, roads, and an artificial channel race remain essentially undisturbed within the Loop 390 corridor and the privately-owned portions of the site, although the eastern third was destroyed by a modern lumber mill. Although the site is listed on the National Register of Historic Places, there is no concerted plan for preservation of this important military-industrial complex.

The 1994 project was directed by David H. Jurney, Principal Investigator, and Thomas E. Speir, Project Director. It consisted of three field schools, a Southern Methodist University graduate seminar in high resolution remote sensing and surveying taught by James M. Adovasio; field excavation, analysis, 
and conservation techniques taught by Brenda Whorton to the 7 th grade of the Dallas Episcopal School; and the NETAS-East Texas Field School taught by David Jurney, Thomas Speir, Velicia Hubbard, and Mike Turner, which focused on vegetation control and removal, remote sensing for building foundations in the northern portion of the site, high resolution mapping, and limited excavations focused on a building interpreted to be a foundry. Approximately 150 participants and guests visited the complex. Ancillary tasks included examination of the Marshall Powder Mill collections at the Texas Archeological Research Laboratory (TARL) in Austin, and inventory of private collections in northeast Texas; visiting the National Archives in Washington; compilation of an archival file in Harrison County; and interviews of descendants of Civil War participants. In addition, a Civil War reenactment of a camp scene was performed by the late Larry Fant. Future tasks include analysis and conservation of artifacts to be curated at TARL, preparation of a final report, and recommendations for the systematic recordation of Civil War sites in northeast Texas.

Despite diligent research in the 1970 s and extensive modern searches, few additional archival sources were located. This significant site has little historical documentation as to the number and types of buildings, their locations, and the activities that were conducted there.
The single map in the National Archives, for instance, was captured by Federal troops in 1864, and only indicates a few of the buildings and none of the earthworks. Apparently, the Confederates were concerned with security, and the commander, Major George D. Alexander, destroyed or removed all records prior to Federal occupation of the site in 1865 . Therefore, the archaeological remains speak the clearest about the Marshall Arsenal's buildings and their functions, and may be the only sure means of reconstructing the layout and design of the arsenal, as well as ancillary fortifications, buildings, and structures within and around Marshall.

\section{REFERENCES}

Luke, C.J.

1978 The Marshall Powder Mill Site:

The 1973-74 Excavation. State Department of Highways and Public Transportation, Publications in Archaeology, Highway Design Division, Report 11. Austin.

Weir, F.A.

1973 The Marshall Powder Mill, a Preliminary Report. Texas Highway Department Publications in Archaeology, Division of Highway Design, Report 3. Austin. 